\title{
THE LARVAL AND POST-LARVAL STAGES OF GYMNAMMODYTES SEMISQUAMATUS (JOURDAIN)
}

\author{
By Jane CAMERon \\ The Marine Biological Station, Port Erin
}

In the course of investigations (1955-8) into the Ammodytidae of the south of the Isle of Man, five species of sand eel were identified: Gymnammodytes semisquamatus (Jourdain, I879), the Smooth Sand Eel; Ammodytes lanceolatus Lesauvage, I825, the Greater Sand Eel; $A$. immaculatus Corbin, I950; A. tobianus Linnaeus, $175^{8}$ ( $=A$. lancea Cuvier), the Lesser Sand Eel; A. marinus Raitt, I934.

Five different types of post-larvae were obtained and investigated. Four of these were the post-larvae of the above four Ammodytes species and the fifth type proved to be Gymnammodytes semisquamatus.

$A$. lanceolatus and $A$. marinus post-larvae were identified according to Einarsson (I95I) and Corbin \& Vati (1949), and A. tobianus was identified according to Einarsson (1955). The results agreed with Einarsson's conclusions on the identification of these post-larvae. Very few post-larvae of A. immaculatus (Corbin \& Vati, I949-Ammodytes Species IV) were obtained and these were identified by vertebral counts as they are externally very similar to $A$. lanceolatus post-larvae.

Previous confusion in the identification of Ammodytes post-larvae has now been cleared up by the investigations of Einarsson (1951, 1955). In I949 Corbin \& Vati published a description of four Ammodytidae postlarval types. These were ascribed to the species $A$. lanceolatus, $A$. marinus, A. tobianus and Ammodytes Species IV ( $=$ A. immaculatus Corbin, 1950a). Corbin noted a marked discrepancy between vertebral counts made on the post-larvae ascribed to $A$. tobianus and counts made on a sample of adult A. tobianus. Subsequent investigations into Ammodytes post-larvae by Einarsson (I95I) proved that the A. marinus post-larvae of Corbin \& Vati (and of Kändler, I94I) were correctly identified, but that the post-larval type which Corbin \& Vati called $A$. tobianus was in fact $A$. lanceolatus.

The post-larval type ascribed by Corbin \& Vati (also by Ford, I920; Kändler, I94I) to $A$. lanceolatus therefore belonged to some other species.

Einarsson (I95I) had no opportunity to examine intact specimens of this post-larval type, but he discussed some of its peculiar features, distinct from other Ammodytidae post-larvae, and suggested the possibility of its being the young of $G$. semisquamatus: 'The data on post-larvae of $A$. lanceolatus 
must be referred to another species of Ammodytidae, not definitely known as yet, but most probably G. semisquamatus.' After the present work was completed it was brought to my notice that the Council of the Marine Biological Association of the United Kingdom reported (F. mar. biol. Ass. U.K., I954, Vol. 33, p. 77I) that Mr P. G. Corbin obtained several artificial fertilizations of the eggs of G. semisquamatus in 1953 , and that the larvae from the artificial fertilizations provided independent confirmation of Einarsson's identification.

Post-larvae of this type are abundant in the plankton off the south of the Isle of Man from May to September, and it has been possible to obtain large numbers for investigation.

A series of larvae and post-larvae from $3 \mathrm{~mm}$ through the late post-larval to juvenile stages of $40-50 \mathrm{~mm}$ have been examined and there is no doubt that these post-larvae are $G$. semisquamatus.

Post-larval stages of $G$. semisquamatus can be identified by external characters alone. Several identifying characters were found to be important. These come under the following headings and are discussed below: (I) the pattern of pigmentation, (2) 'teeth' on the upper jaw, (3) protrusibility of the upper jaw, (4) vomerine teeth, (5) juvenile and adult characteristics.

During the course of post-larval development the above characters overlap successively so as to give a complete sequence of specific characters from the smallest larva obtained $(3 \mathrm{~mm})$ to juvenile fish of $30-50 \mathrm{~mm}$ in which adult characteristics are already developing.

\section{CHARACTERS OF POST-LARVAL \\ GYMNAMMODYTES SEMISQUAMATUS}

\section{The pattern of pigmentation}

The nomenclature of the post-larval pigmentation is shown in Text-fig. I (after Corbin \& Vati, I949).

The presence of a ventral fin-membrane pigment row is specific to the early post-larvae of $G$. semisquamatus. It occurs in the smallest specimens obtained and persists through all stages until about $19 \mathrm{~mm}$. In the post-larvae of the Ammodytes species there is no ventral fin-membrane pigment at any stage.

\section{'Teeth' on the upper jaw}

At about $7 \mathrm{~mm}$ the post-larva develops a row of tooth-like structures along the outer edge of the rim of the upper jaw (pre-maxilla). These are pointed, shaped like thorns and can be seen without staining with alizarin. They are found only in the post-larvae of G. semisquamatus and not in the post-larvae of the Ammodytes species. They persist until the post-larva is $20-25 \mathrm{~mm}$ long, by which length the growing tissues around the lips have obliterated the larval 'teeth'. 


\section{Protrusibility of the upper jaw}

This becomes detectable at 8-10 $\mathrm{mm}$ and from then on it is a very important feature. Protrusibility becomes increasingly more marked in increasingly larger post-larvae and this therefore rules out the possibility of the postlarvae belonging to the species $A$. lanceolatus or $A$. immaculatus, both of which species have a non-protrusible jaw.

In juvenile and adult $G$. semisquamatus the upper jaw is very protrusible. When the upper jaw is shot forward during feeding the whole mouth forms a long tube. The mouth can be protruded farther than that of either A.tobianus or A. marinus and the mechanism of protrusion and the shape of the head and jaws are quite characteristic in juvenile and adult G. semisquamatus. These adult features of the head and jaws can be recognized to be developing in the post-larva of $18 \mathrm{~mm}$ or earlier. From there they can be traced through different stages to the juvenile.

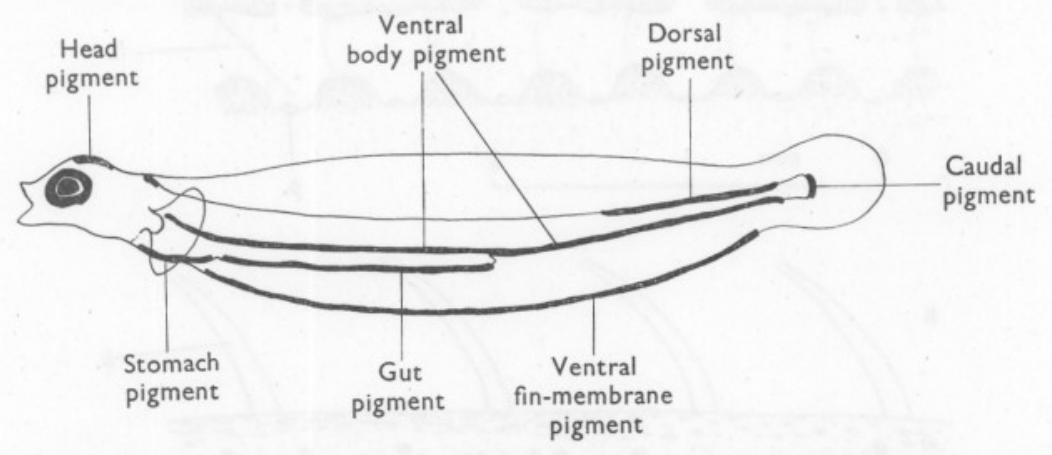

Text-fig. I. Diagram showing the nomenclature of the pigment rows.

(After Corbin \& Vati, 1949.)

\section{Vomerine teeth}

A pair of sharp downward- and outward-curving teeth begin to develop on the post-larval vomer (figured by Einarsson, I95I) at about I2-I5 mm length. These were previously taken to be diagnostic characters of $A$. lanceolatus, but their structure and the shape of the vomer is different from that in the A. lanceolatus post-larva (see Einarsson, 1951, pp. 24-5, figs. 6, 7). Moreover, the vomerine teeth of $A$. lanceolatus are not visible until the post-larva has reached $20-25 \mathrm{~mm}$ in length; they persist throughout development and are present in the adult. The vomerine teeth of post-larval G. semisquamatus do not persist in the adult but they remain until after the ventral fin-membrane pigment row and the 'teeth' on the upper jaw have gone. They disappear when the fish is between $40 \mathrm{~mm}$ and $50 \mathrm{~mm}$ long, but by then it is a late post-larva-to-juvenile, some of the adult characteristics being already present and the fish recognizable as G. semisquamatus by the criteria applied to adults. 
The important identifying characters of juvenile and adult G. semisquamatus are as follows.

(I) The structure of the lateral line is characteristic (see Text-fig. 2). Transverse side-channels of the lateral-line canal lead to the pores, in contrast to the lateral line of the Ammodytes species which is linear (Duncker \& Mohr, I939, p. II, fig. I; Jourdain, I879, figs. I3, I4). The scales along the lateral line are not pierced by pores as they are in the Ammodytes species.
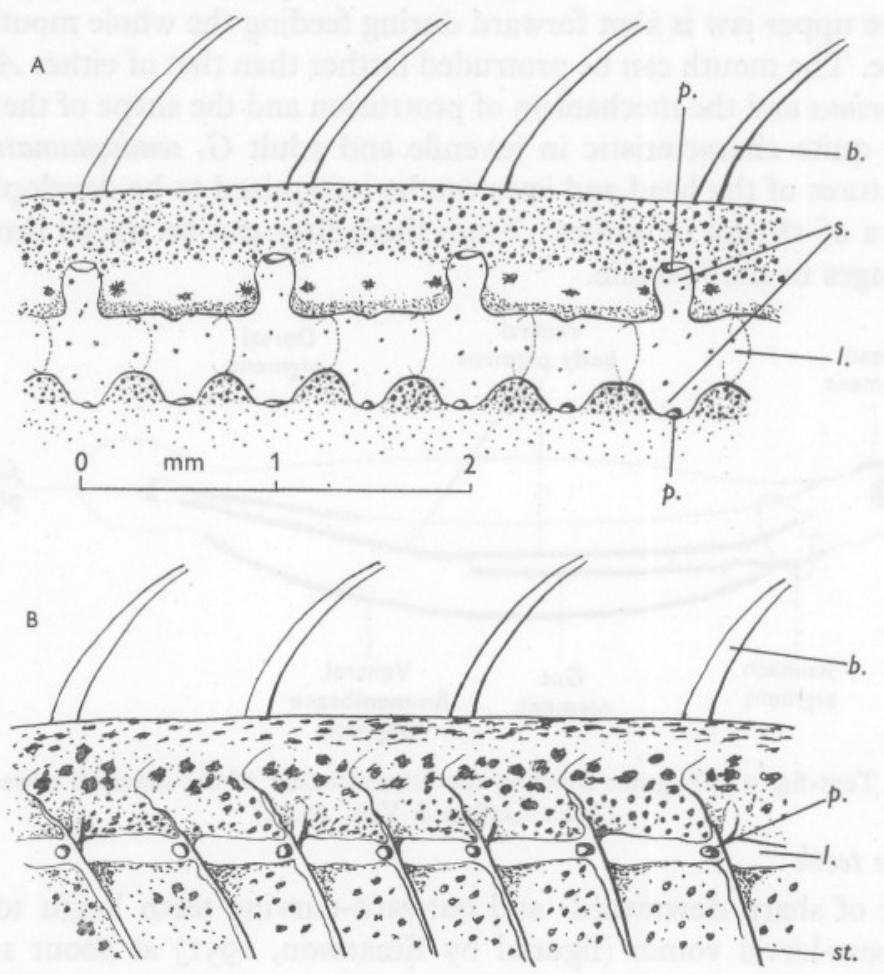

Text-fig. 2. The structure of the lateral line (lateral view). A, Gymnammodytes semisquamatus. B, Ammodytes marinus. $b$, base of dorsal fin-ray; $l$, lateral line canal; $p$, pore; $s$, side-channels; st, skin-folds or striae.

(2) The upper jaw is markedly protrusible.

(3) There are no vomerine teeth.

(4) The body is smooth and unstriated.

(5) The ventro-lateral skin-fold extends from the base of the pectoral fin to a point level with, or just beyond, the tip of the pectoral fin when this is pointing towards the tail.

(6) The colour of the head and back is golden-brown or dark purplish brown, while the sides and belly are silvery and iridescent. 
A diagnosis of the species G. semisquamatus from the newly hatched larva, up to the stage at which it can be recognized by criteria applied to the adult, is given below.

\section{DIAGNOSIS}

\section{Larvae, 3-4 mm (Pl. I, figs. I, 2)}

Ventral fin-membrane pigment row present. No 'teeth' on upper jaw. Upper jaw cannot be protruded. No vomerine teeth.

Yolk-sac present, partially absorbed. The yolk-sac may be completely absorbed at $4 \mathrm{~mm}$. No dorsal or head pigment present. Stomach pigment consists of four, five or six brown, large and many-branched melanophores along the ventral mid-line of the yolk-sac, with two or more melanophores on the sides of the yolk sac. Ventral body pigment shows clearly pre- and post-anally. The ventral fin-membrane pigment row extends from the stomach region nearly to the tail.

\section{Post-larvae, 5-7 mm (Pl. I, figs. 3, 4)}

Ventral fin-membrane pigment row present. 'Teeth' become visible at $7 \mathrm{~mm}$ (Pl. I, fig. 4). Upper jaw cannot be protruded. No vomerine teeth.

Yolk-sac absent. There may be a single median melanophore over the occipital region of the head. One or two dorsal melanophores are present directly in front of the tail. There are two caudal melanophores ventral to the tip of the notochord. The first rudiments of caudal fin-rays are visible at $6-7 \mathrm{~mm}$.

The notochord is straight.

\section{Post-larvae, 8-10 $\mathrm{mm}$}

Ventral fin-membrane pigment row present. 'Teeth' present on upper jaw. Upper jaw can be protruded at 9-10 mm. Vomerine teeth not visible.

The notochord begins to turn up posteriorly at $9 \mathrm{~mm}$, and at this length caudal fin-rays are beginning to develop. There may now be three to five dorsal melanophores at the posterior end, but usually only two or three. Pigment is otherwise as before.

\section{Post-larvae, II-I9 mm (P1. I, fig. 5; Pl. II, figs. I-3)}

Ventral fin-membrane pigment row present. 'Teeth' present on upper jaw. Upper jaw protrusible and increasingly so with increasing size of fish. Vomerine teeth visible from $\mathrm{I} 2$ to $15 \mathrm{~mm}$.

The notochord is turned up and the tail is in the adult position at II mm (Pl. I, fig. 5). Also at II mm five or six dorsal fin-rays can be seen to be developing midway between anus and tail. Below these, five or six anal fin rays are developing. By $19 \mathrm{~mm}$ all anal fin-rays are present, and dorsal fin-rays extend from the tail farther forward than the level of the anus.

Head pigment begins to show at $\mathrm{II}-\mathrm{I} 2 \mathrm{~mm}$-two stellate melanophores at first, later up to five. Dorsal pigment is now at maximum for post-larvae. It consists of never more than five melanophores all close to the tail. The dorsal pigment in the post-larva rarely extends as far as half-way between the tail and the level of the anus. The ventral body pigment is becoming obscured pre-anally by the downward growth of the abdomen walls but can still be seen in side view as about seventeen dark spots. Stomach pigment is now made up of four to five small compact melanophores. Gut pigment consists of about seventeen very small black dots extending from stomach to anus. Both stomach and gut pigment are usually lost at a post-larval length of 
16-17 $\mathrm{mm}$. Ventral fin-membrane pigment becomes more reduced as anal fin-rays develop. By $19 \mathrm{~mm}$ there are only a few ventral fin-membrane melanophores remaining - all anterior to the anus. In fresh or freshly preserved specimens of I6-I9 mm there are very small well-defined orange chromatophores along the ventral surface of the gut and stomach, and lines of these chromatophores extend forwards between the gills (not shown in illustration).

\section{Post-larvae, 20-24 $\mathrm{mm}$ (Pl. II, fig. 4)}

Ventral fin-membrane pigment row absent. 'Teeth' present on upper jaw. Upper jaw protrusible. Vomerine teeth present.

Dorsal fin-rays extend to half-way between head and anus. There is more pigment on the head, consisting of four or more stellate melanophores. The occipital melanophore remains and there is usually one melanophore or a small cluster on the operculum behind the eye. There is now no trace of stomach or gut pigment. The dorsal pigment is the same as before. Ventral body pigment is still visible but obscure in the pre-anal region. There is a single, central caudal melanophore. Ventral orange chromatophores are as above.

\section{Post-larvae, 25-29 $\mathrm{mm}$}

'Teeth' no longer visible on upper jaw. Upper jaw protrusible. Vomerine teeth present.

The full number of dorsal fin-rays are present. The dorsal fin extends forward to a point level with the tip of the pectoral fin when this is turned to the posterior.

Ventral body pigment is now very obscured behind the abdomen wall but is still well-marked post-anally. There is now more head pigment.

\section{Post-larvae, $30-37 \mathrm{~mm}$}

No specimens examined.

\section{Post-larva-to-juvenile, 38-47 mm (P1. II, fig. 5)}

Upper jaw markedly protrusible. Vomerine teeth present. Vomerine teeth are reduced but still visible at $47 \mathrm{~mm}$.

Brown juvenile pigment is developing especially on the top of the head, around the jaws, and along the dorsal mid-line at the base of the dorsal fin on each side. Brown chromatophores are also present along the lateral lines, at the base of the caudal fin and along the caudal fin-rays.

The lateral lines are close to the base of the dorsal fin, and extend on either side of the dorsal fin from a point level with the posterior edge of the operculum and the base of the pectoral fin to a small distance in front of the tail. The lateral lines already show adult characteristics.

\section{Fuveniles, 48-50 $\mathrm{mm}$ (Pl. II, fig. 6)}

Upper jaw markedly protrusible. Vomerine teeth lost.

The fish are otherwise as above $(38-47 \mathrm{~mm})$ with increasing juvenile-adult pigment forming along the lateral lines (large brown chromatophores), on the head, the sides of the body and on the caudal fin.

\section{fuveniles, 50-60 $\mathrm{mm}$}

The juveniles resemble adults in colour and proportions. 


\section{NUMBER OF VERTEBRAE}

Vertebral counts were made on I50 adult G. semisquamatus and also on 33 post-larvae. The post-larvae were stained with alizarin and afterwards cleared. The urostyle was included in all counts.

The results are given in Tables I and 2, together with the results of Corbin \& Vati (1949) and Corbin (1950 b) which are the only vertebral counts of G. semisquamatus I have been able to obtain. The Celtic Sea post-larvae of Corbin \& Vati (1949) were ascribed to $A$. lanceolatus but are now known to have been $G$. semisquamatus (see p. I7 above).

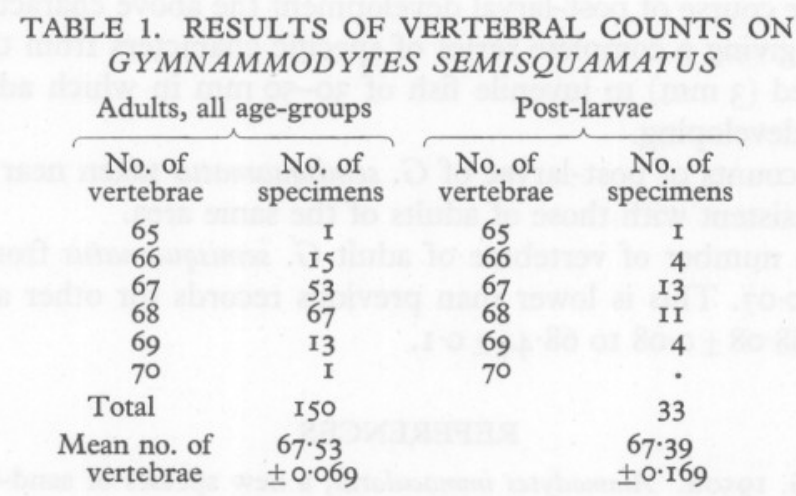

TABLE 2. THE NUMBER OF VERTEBRAE IN GYMNAMMODYTES SEMISQUAMATUS

\begin{tabular}{|c|c|c|c|c|c|}
\hline $\begin{array}{l}\text { Area and age of } \\
\text { specimens }\end{array}$ & Author & $\begin{array}{l}\text { No. of } \\
\text { speci- } \\
\text { mens }\end{array}$ & $\begin{array}{l}\text { Range of } \\
\text { no. of } \\
\text { vertebrae }\end{array}$ & $\begin{array}{l}\text { Mean no. } \\
\text { of } \\
\text { vertebrae }\end{array}$ & $\begin{array}{l}\text { Standard } \\
\text { error } \\
\text { of mean }\end{array}$ \\
\hline $\begin{array}{l}\text { West Scotland and } \\
\text { northern North Sea } \\
\text { adults }\end{array}$ & Corbin \& Vati (1949) & $5 \mathrm{I}$ & $65-70$ & $68 \cdot 16$ & \pm 0.144 \\
\hline $\begin{array}{l}\text { Celtic Sea post- } \\
\text { larvae }\end{array}$ & Corbin \& Vati (1949) & 52 & $64-70$ & $68 \cdot 08$ & \pm 0.082 \\
\hline Plymouth adults & Corbin (1950b) & 108 & $66-72$ & $68 \cdot 44$ & \pm 0.098 \\
\hline $\begin{array}{l}\text { Irish Sea adults } \\
\text { Irish }\end{array}$ & Present records & 150 & $65-70$ & $67 \cdot 53$ & \pm 0.069 \\
\hline Irish Sea post-larvae & Present records & 33 & $65-69$ & $67 \cdot 39$ & \pm 0.169 \\
\hline
\end{tabular}

The range of number of vertebrae of the Irish Sea specimens is within the ranges for previous records, but the mean number of vertebrae for the Irish Sea is slightly lower than previous records.

\section{SUMMARY}

Larval and post-larval stages of Gymnammodytes semisquamatus are described from recently hatched larvae up to juvenile stages.

Late post-larvae and juveniles are identified as G. semisquamatus by the criteria applied to adults. 
The Ammodytidae post-larvae ascribed by Ford (I920), Kändler (I94I) and Corbin \& Vati (I949) to Ammodytes lanceolatus, are shown to be identical with post-larval stages of $G$. semisquamatus.

G. semisquamatus post-larvae can be isolated from all other Ammodytidae by the following external characters which, occurring in combination, are diagnostic: (I) presence of ventral fin-membrane pigment row, (2) tooth-like structures on the edge of the upper jaw, (3) protrusible upper jaw, (4) larval vomerine teeth lost in development when the fish is between 40 and $50 \mathrm{~mm}$ long, and (5) adult characters of G. semisquamatus which are present in the late post-larval and juvenile stages.

During the course of post-larval development the above characters overlap successively giving a complete series of specific characters from the smallest larva obtained $(3 \mathrm{~mm})$ to juvenile fish of $30-50 \mathrm{~mm}$ in which adult characteristics are developing.

Vertebral counts of post-larvae of G. semisquamatus taken near the Isle of Man are consistent with those of adults of the same area.

The mean number of vertebrae of adult $G$. semisquamatus from this area was $67.53 \pm 0.07$. This is lower than previous records for other areas which range from $68 \cdot 08 \pm 0.08$ to $68 \cdot 44 \pm 0 \cdot 1$.

\section{REFERENCES}

Corbin, P. G. r950a. Ammodytes immaculatus, a new species of sand-eel found in European seas. Nature, Lond., Vol. 166, pp. 525-26.

- 1950 b. The occurrence of the smooth sand-eel Gymnammodytes semisquamatus (Jourdain) in the Plymouth area, with notes on G. cicerelus (Rafinesque), and G. capensis (Barnard). F. mar. biol. Ass. U.K., Vol. 29, pp. 83-95.

Corbin, P. G. \& VATI, V., I949. The post larval sand-eels (Ammodytidae) of the Celtic Sea and Plymouth area. F. mar. biol. Ass. U.K., Vol. 28, pp. 287-313.

Duncker, G. \& Mohr, E., 1939. Revision der Ammodytidae. Mitt. zool. Mus. Berl., Bd. 24, Heft I, pp. 8-3I.

EINARSSON, H., I95I. The post-larval stages of sand-eels (Ammodytidae) in Faroe, Iceland and W-Greenland waters. Acta nat., islandica, Vol. I, No. 7, 75 pp.

1955. On the post-larval stages of Ammodytes lancea Cuvier. Acta nat. islandica, Vol. 2, No. I, 7 pp.

ForD, E., 1920. The post-larval stages of Ammodytes species captured during the cruises of S.S. Oithona in Plymouth waters in the year 1919. F. mar. biol. Ass. U.K., Vol. I2, pp. 24I-48.

Jourdain, S., I879. Sur les Ammodytes des côtes de la Manche. Rev. Sci. nat., Sér. 2, T. I, pp. 203-10.

KÄNDLER, R., I94I. Untersuchungen über Fortpflanzung, Wachstum und Variabilität der Arten des Sandaals in Ost- und Nordsee, mit besonderer Berücksichtigung der Saissonrassen von Ammodytes tobianus L. Kieler Meeresforsch., Bd. 5, Heft r, pp. 45-145. 
J. MAR. BIOL. Ass. U.K., 38 (I)

CAMERon. PLATE I

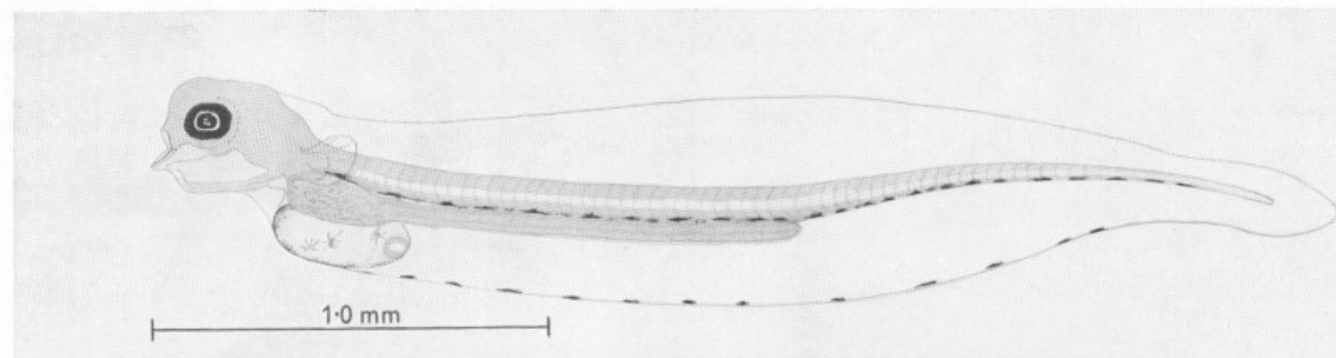

1

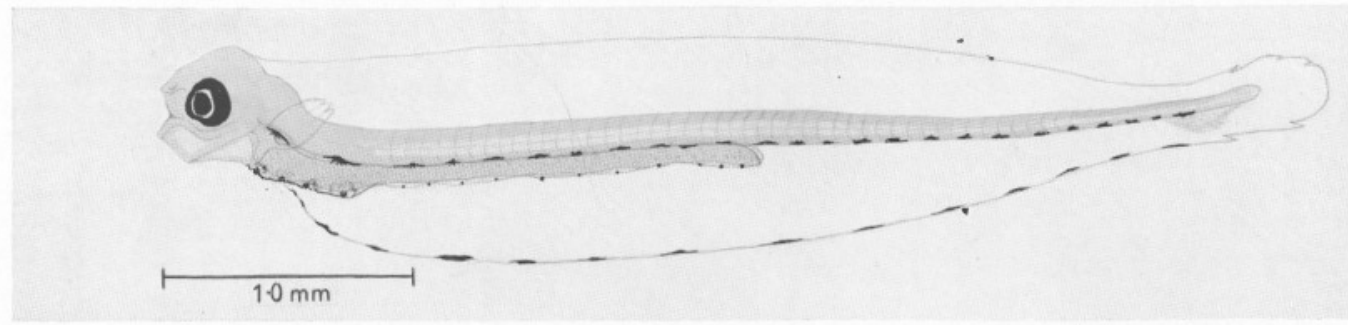

2
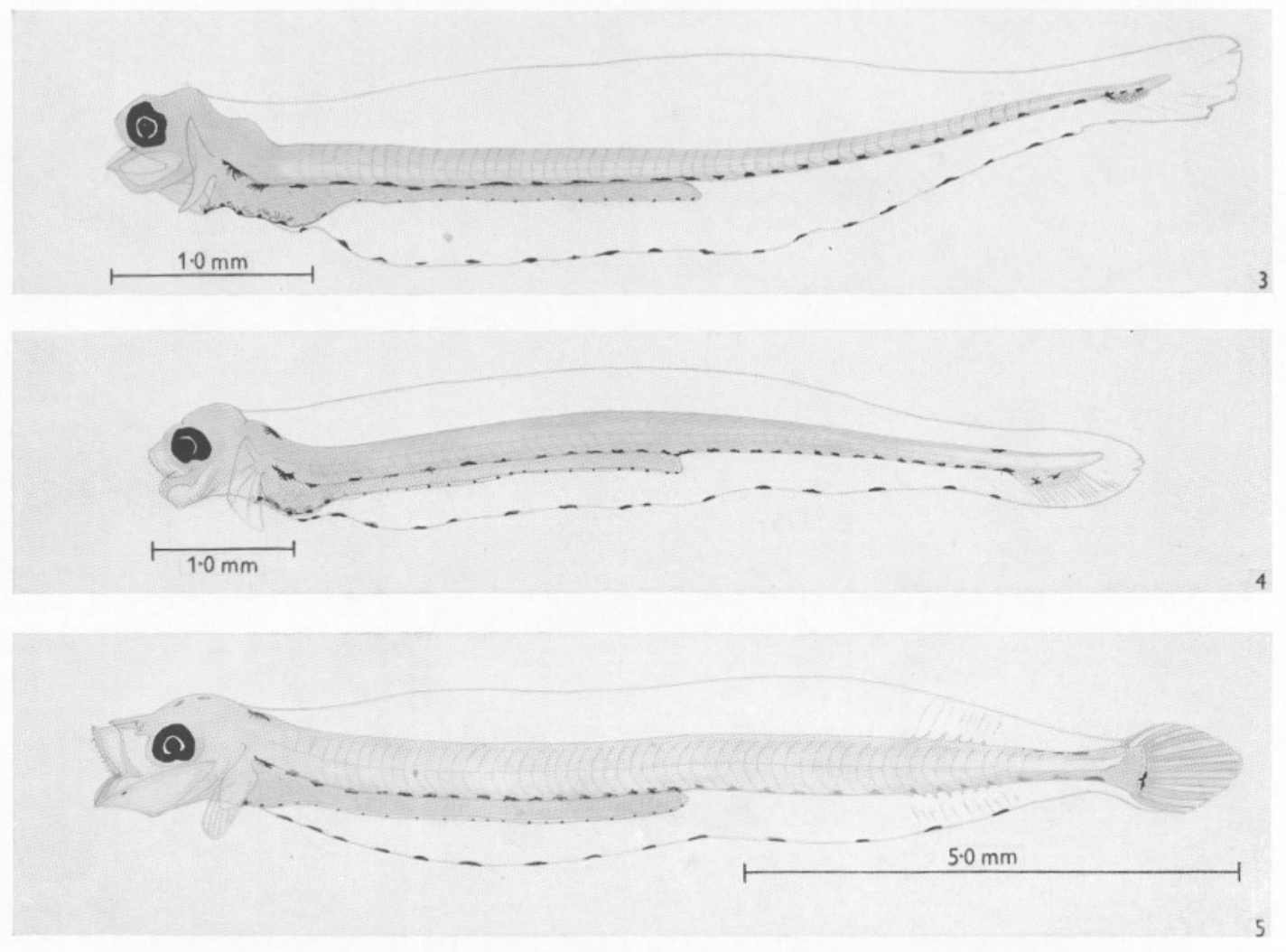

(Facing p. 24) 

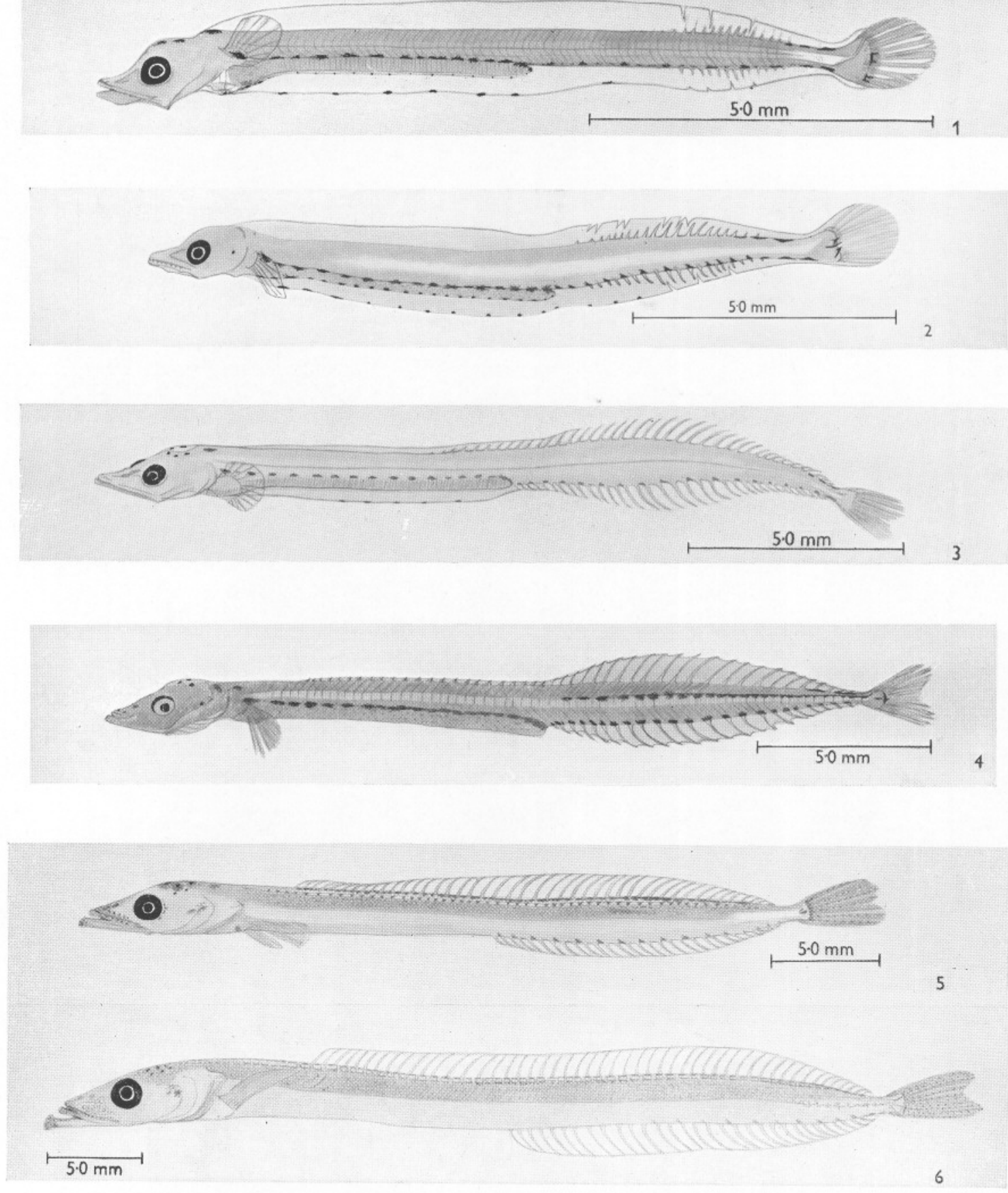


\section{EXPLANATION OF PLATES I AND II}

Development stages of Gymnammodytes semisquamatus larvae and post-larvae. The drawings were made from specimens preserved in formalin. Measurements represent total length.

\section{Plate I}

Fig. I. Larva, $3 \mathrm{~mm}$.

Fig. 2. Post-larva, 4.75 mm.

Fig. 3. Post-larva, 5.75 mm.

Fig. 4. Post-larva, 7.0 mm.

Fig. 5. Post-larva, II $75 \mathrm{~mm}$.

\section{Plate II}

Fig. I. Post-larva, 12.5 mm.

Fig. 2. Post-larva, $14.0 \mathrm{~mm}$.

Fig. 3. Post-larva, 19.5 mm.

Fig. 4. Post-larva, 24.0 mm.

Fig. 5. Post-larva, $38.0 \mathrm{~mm}$.

Fig. 6. Juvenile, $48.0 \mathrm{~mm}$. 